\title{
Effects of Quercetin Induced Cell Death on a Novel Gene "URG4/URGCP" Expression in Leukemia Cells
}

\section{Yavuz Dodurga ${ }^{1 *}$, Cigir Biray Avci ${ }^{2}$, Lale Satiroglu-Tufan N ${ }^{3}$, Sunde Yilmaz Susluer ${ }^{2}$, Ozlem Dogan Sigva Z ${ }^{2}$, Guray Saydam ${ }^{4}$ and Cumhur} Gunduz ${ }^{2}$

${ }^{1}$ Pamukkale University, School of Medicine, Department of Medical Biology, Denizli

${ }^{2}$ Ege University, School of Medicine, Department of Medical Biology, Izmir

${ }^{3}$ Pamukkale University, School of Medicine, Department of Medical Genetics, Denizli

${ }^{4}$ Ege University, School of Medicine, Department of Hematology, Izmir

\begin{abstract}
The present study aimed to investigate anti-proliferative and apoptotic effects of quercetin on human leukemia cells and effects of quercetin-induced cell death on a novel gene Up-regulated gene 4/upregulator of cell proliferation (URG4/URGCP), in leukemia cells. URG4/URGCP expression is determined by using RT-PCR. IC $\mathrm{C}_{50}$ of quercetin was determined as 25 microM in CCRF-CEM, HL-60 and K562 cells. In IC I0 $_{50}$ dose group, URG4/URGCP expression was decreased $99 \%$ in HL-60 cells, 90\% in CCRF-CEM cells, and 52\% (24 hour) - 99\% (72 hour) in K-562 cells. URG4/URGCP may play important roles in the development of leukemia, and might be a useful molecular marker for predicting the prognosis of leukemia via quercetin treatment.
\end{abstract}

Keywords: Quercetin; URG4/URGCP; Leukemia cells

\section{Introduction}

Various hypotheses exist about having higher cancer risk reduction by consuming fruits and vegetables rich in terms of phytochemicals. Although they are the frequently consumed compounds of human diet, biological and pharmacological features of flavonoids are yet to be defined. Major effects of flavonoids are reported to occur in consequence of release of radicals. Another possible mechanism is the activation of flavonoids over various enzyme systems. Cellular activities of these chemicals are not well known as, along with protecting cells from oxidative stress, flavonoids can contribute apoptosis and genotoxicity of tumor cells by their pro-oxidant features [1].

Anti-cancer mechanisms, anti-oxidants, anti-inflammatory and anti-proliferative activities of flavonoids are associated with inhibition of bioactive enzymes and induction of detoxification enzymes [2]. Quercetin is a type of plant-based chemical flavonoid, shown to have anti-inflammatory and antioxidant properties. It has been promoted as being effective against a wide variety of diseases, including cancer and reported to affect cell cycle kinetics, proliferation and induction of apoptosis $[3,4]$. There is limited data related with the antagonistic or synergistic interactions among polyphenols in fruits and vegetables. Characterization of potential interactions among these compounds can be effective in determination of the effects of nutrients contain polyphenol in prevention of cancer development [5].

Up-regulated gene 4/Upregulator of cell proliferation (URG4/ URGCP), GeneBank NM_017920), a novel gene located on 7p13 and originally identified by Satiroglu-Tufan NL, encodes 922 amino acid in cytoplasm. Over-expression of URG4/URGCP in HepG2 cells promoted hepatocellular growth and survival in tissue culture and in soft agar, and accelerated tumor development in nude mice [6]. URG4/ $U R G C P$ is strongly expressed in hepatocellular carcinoma, gastric cancer and osteosarcoma. Hence, URG4/URGCP may be a putative oncogene that contributes importantly to multistep carcinogenesis and cell cycle regulation. The present study examined the expression of $U R G 4 / U R G C P$ in leukemia cells and possible association of $U R G 4 /$ $U R G C P$ and leukemogenesis has been analyzed for the first time.
This study aimed to investigate anti-proliferative and apoptotic effects of quercetin on human leukemia cells and effects of quercetininduced cell death on a novel gene URG4/URGCP expression in leukemia cells.

\section{Material and Methods}

\section{Chemicals and reagents}

Quercetin (Sigma Chemical Co., St Louis Missouri) is diluted in $0.5 \%$ dimethylsulphoxide (DMSO) for the assays. Cell proliferation assay (XTT) was supplied from Roche Diagnostics. For determination of URG4/URGCP gene expression, TaqMan Master Kit (Roche Diagnostics) was obtained from Roche Applied Science, Mannheim, Germany, respectively. All other tissue culture supplies were obtained from Corning Incorporated (USA) unless otherwise specified.

\section{Cell lines and cultures}

Human T-cell acute lymphoblastic leukemia cell line (CCRF-CEM; ATCC number: CCL-119), Human promyelocytic leukemia cells (HL60; ATCC number: CCL-240), Human erythromyeloblastoid leukemia (K-562; ATCC number: CCL-243) cell lines were used as model cell lines in this study which were provided by ATCC.

\section{Cell culture and preparation of cytotoxicity experiments}

All tumor cell lines grown in RPMI-1640 medium containing $2 \mathrm{mM}$ L-glutamine supplemented with $10 \%$ fetal bovine inactivated serum

*Corresponding author: Yavuz Dodurga, Pamukkale University, Department of Medical Biology, Kınıklı Kampüsü Morfoloji Binasi Kat:3, Kınıklı / Denizli, Turkey, Tel: +90 25829625 34; Fax: +90 258296243317 65; E-mail: yavuzdodurga@gmail.com

Received November 28, 2011; Accepted December 26, 2011; Published December 28, 2011

Citation: Dodurga Y, Avci CB, Lale Satiroglu-Tufan N, Susluer SY, Ozlem Dogan Sigva Z, et al. (2012) Effects of Quercetin Induced Cell Death on a Novel Gene "URG4/URGCP" Expression in Leukemia Cells. J Cancer Sci Ther 4: 006-009. doi:10.4172/1948-5956.1000102

Copyright: (c) 2012 Dodurga Y, et al. This is an open-access article distributed under the terms of the Creative Commons Attribution License, which permits unrestricted use, distribution, and reproduction in any medium, provided the original author and source are credited. 


\begin{tabular}{|l|l|l|l|}
\hline Gene & ForwardPrimer & Reverse Primer & Probe (Roche) \\
\hline URG4/URGCP & cgaacagctgtggccatt & ccataacggaactcgcaatc & Ggaaggag \\
\hline GAPDH & gaaggtgaaggtcggagtc & gaagatggtgatgggatttc & caagcttcccgttctcagcc \\
\hline
\end{tabular}

Table 1: Primers and probes of genes.

and $1 \%$ penicillin/streptomycin were maintained at a density of $5 \times 10^{5}$ cells $/ \mathrm{ml}$ in a standard cell culture incubator at $37^{\circ} \mathrm{C}$, humidified $95 \%$ air, and $5 \% \mathrm{CO}_{2}$ atmosphere. Prior to any experiment, cells were split at $5 \times 10^{5}$ cells $/ \mathrm{ml}$ in the RPMI 1640 medium and cell suspensions was aliquoted into flasks for subsequent treatments. Quercetin diluted in RPMI 1640 was used in treatments of $12.5 \mu \mathrm{M}, 25 \mu \mathrm{M}, 50 \mu \mathrm{M}, 75 \mu \mathrm{M}$, $100 \mu \mathrm{M}$.

\section{Analysis of cell viability and cytotoxicity}

Cytotoxic assays and determination of $\mathrm{IC}_{50}$ doses of quercetin in leukemia cells were performed by using trypan blue dye exclusion and XTT assay [15-17] as indicated in manufacturers' instruction.

Apoptosis was determined morphologically by fluorescence microscopy following the staining with acridine orange and ethidium bromide. Cells were washed in cold PBS and adjusted to the cell density to $1 \times 10^{6}$ cells $/ \mathrm{ml}$ in PBS. Acridine orange and ethidium bromide (1:1) $(\mathrm{v} / \mathrm{v})$ were added to the cell suspension in final concentrations of $100 \mu \mathrm{g} /$ $\mathrm{ml}$ and then cells were incubated for $30 \mathrm{~min}$. The cellular morphology was evaluated by fluorescent microscopy (Olympus, Japan). Apoptotic cells were essentially characterized by nuclear condensation of chromatin and/or nuclear fragmentation. Three hundred cells were evaluated for apoptosis and/or necrosis for each sample. When more than $50 \%$ of the pre-apoptotic plus apoptotic to total cell ratio were positive, the result was accepted positive for apoptosis [16,17].

Cytotoxicity $(\%)=(1-\mathrm{A}$ of experiment well/A of positive control well) $\mathrm{x} 100$

\section{Relative quantification of URG4/URGCP}

Real-time quantitative RT-PCR analyses of $U R G 4 / U R G C P$ gene was performed with Light cycler instrument and software (Table 1). Glyceraldehyde-3-phosphate dehydrogenase (GAPDH "housekeeping" gene) was chosen as a standard to control the variability in amplification. PCR was performed by using TaqMan Master Kit (Roche Diagnostics) according to the instructions of the manufacturer. Studied genes target probe was labeled at the 5 ' end with the reporter dye molecule 6-carboxyfluorescein (FAM). The GAPDH target probe was labeled with 6-carboxyfluorescein. Both probes were labeled with the quencher fluor 6-carboxytetramethylrhodamine (TAMRA) at the 3' end. To quantify genes mRNA from cell culture, we constructed a calibration curve (Error: 0.100 Efficiency: 1,790) using copy number $\left(10^{8}, 10^{7}, 10^{6}\right.$, $10^{5}, 10^{4}, 10^{3}, 10^{2}$ and 10$)$ variations of $G A P D H$ gene. Relative ratio (RR) of gene expressions was calculated using the formula:

$\mathrm{RR}=$ Copy number of gene/Copy number of GAPDH $\mathrm{x} 1000$.

\section{Results}

Quercetin exerts its cytotoxic effect on HL-60, CCRF-CEM and K562 cells in a time- and dose-dependent fashion. We determined the relative reduction in the cell number that evolved in cultures of three cell lines. Assays were performed to determine CCRF-CEM, HL-60 and K562 leukemia cells viability, URG4/URGCP gene expression and changes occurring in this parameter in quercetin-treated samples.

These experiments aimed to assess the best concentration of quercetin to be used in CCRF-CEM, HL-60 and K562 leukemia cell lines, at different concentrations, ranging from $12.5 \mu \mathrm{M}$ to $100 \mu \mathrm{M}$. Cell viability, evaluated by trypan blue exclusion test, was determined after 24, 48, $72 \mathrm{~h}$ exposure to quercetin and are shown in Figure 1. The cell numbers (using trypan blue dye exclusion) as well as cell metabolic rate (by using XTT assay) were also determined. The $\mathrm{IC}_{50}$ of quercetin was found to be $25 \mathrm{mM}$ revealed by trypan blue dye exclusion test as well as it was confirmed by XTT assay (Figure 1, Figure 2). On the other hand, quercetin induced apoptosis in HL-60 and K562 cell lines, correlated with $\mathrm{IC}_{50}$ dose, were increased as $70 \%$ and $65 \%$, respectively (Figure 3 ).
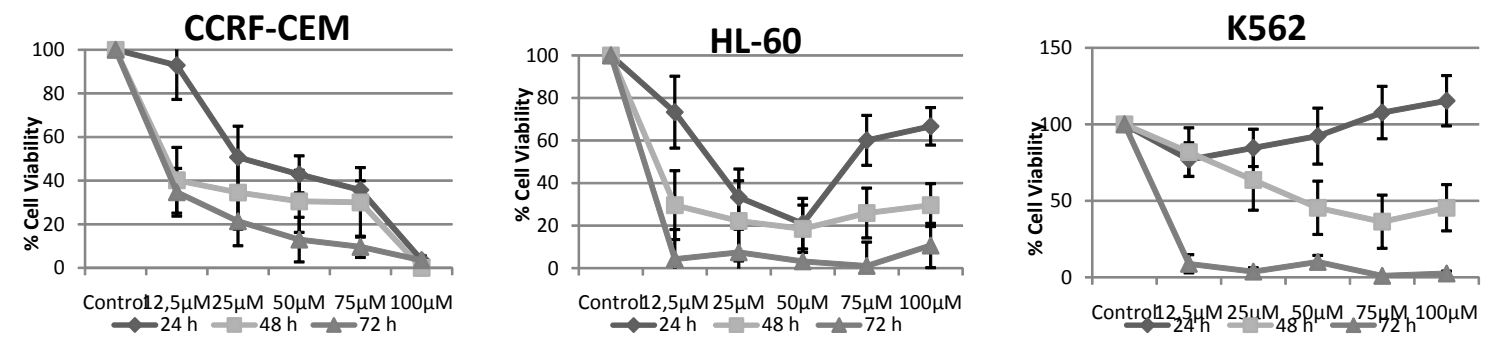

Figure 1: Results of Tyripan Blue Dye Assay.
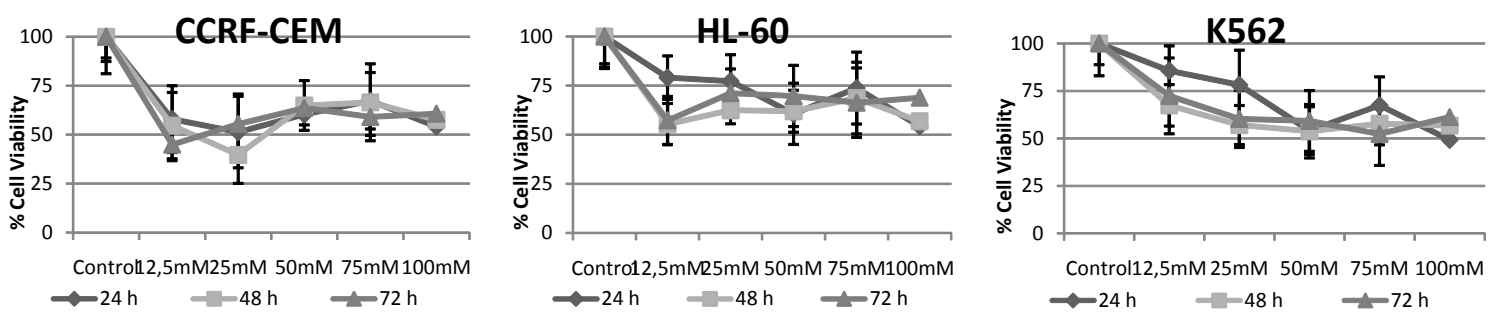

Figure 2: Results of XTT assay. 

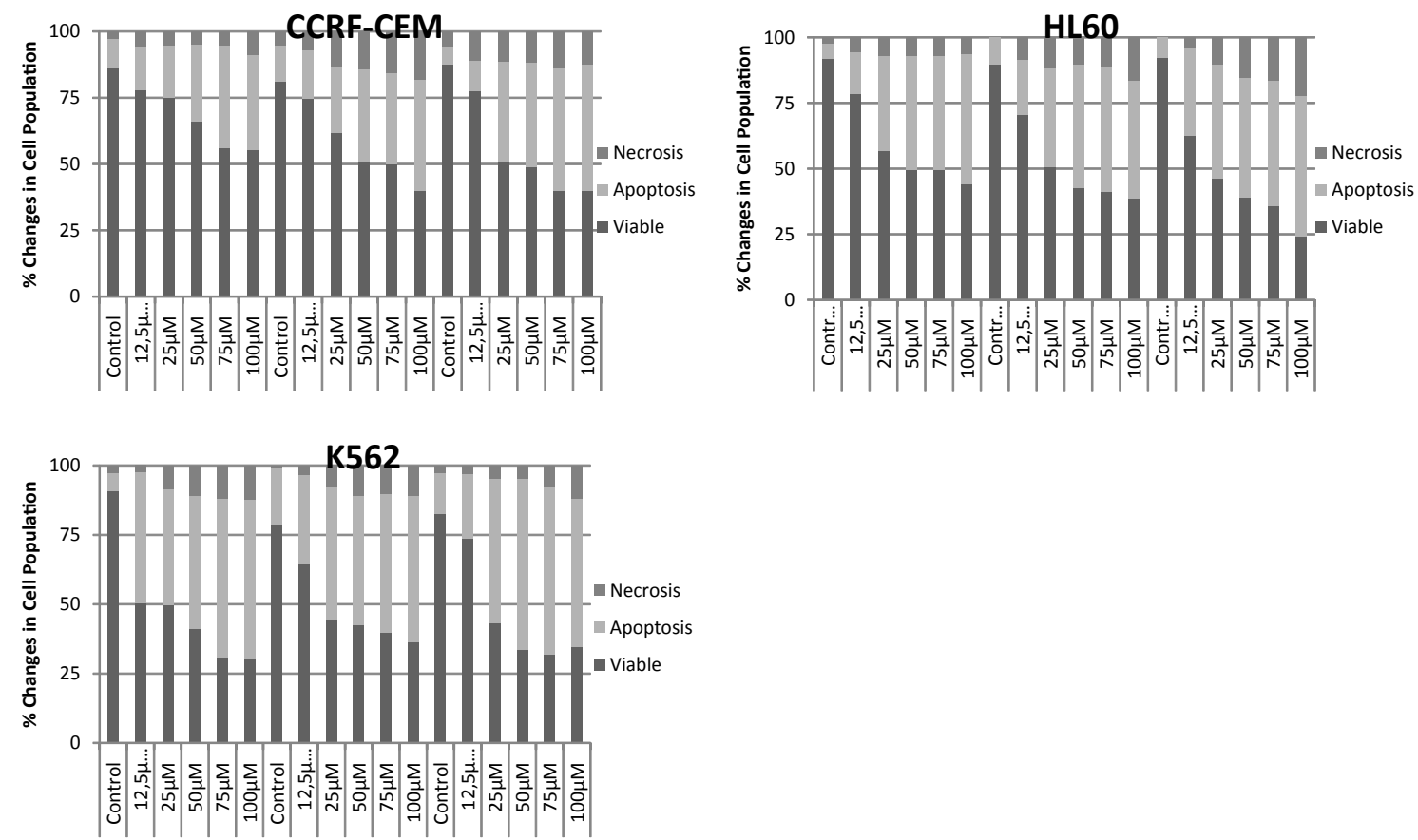

Figure 3: Apoptosis ratio of Ethidium Bromide/Acridine Orange assay.
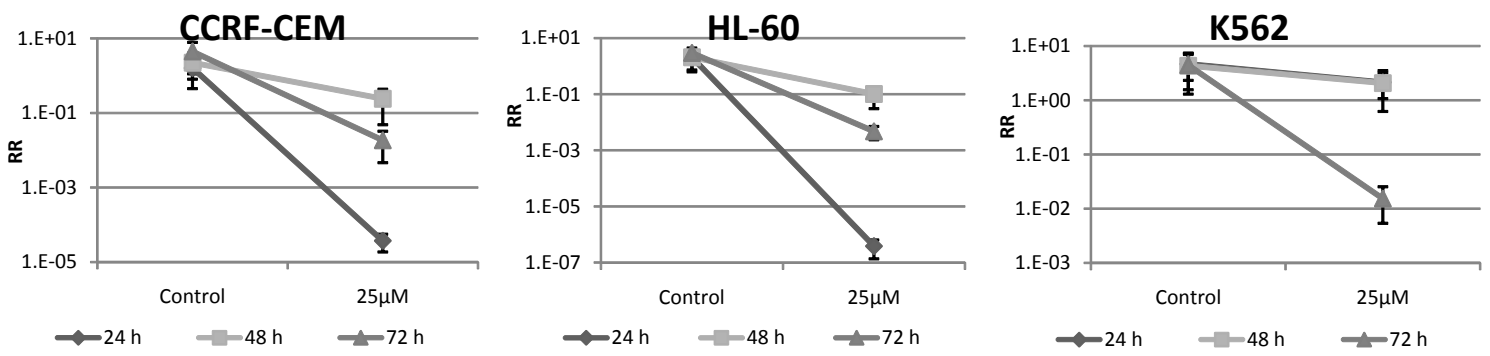

Figure 4: URG4/URGCP mRNA expression ratio.

Expression of $U R G 4 / U R G C P$ mRNA results showed that there was slight decrease in a time-dependent manner on all three cell lines. The averages of $U R G 4 / U R G C P$ mRNA gene expression in control groups of HL-60, K-562 and CCRF-CEM cells were found 2.73, 4.48 and 2.76, respectively. In $\mathrm{IC}_{50}$ dose group, URG4/URGCP gene expression was decreased 99\% in HL-60 cells, 90\% in CCRF-CEM cells, and 52\% (24 hour) - 99\% (72 hour) in K-562 cells (Figure 4).

\section{Discussion}

Quercetin has found to affect some types of cancer cells in several studies done in cell cultures. In a previous work described by Shen et al., it is demonstrated that quercetin was able to induce apoptosis in HL-60 human leukemia cell line. They reported that $\mathrm{IC}_{50}$ is found to be $80 \mu \mathrm{M}$ for viability of the cells. They thought that the induction of apoptosis by quercetin is consistent with the activation of apoptotic machinery including activating the caspase 3 cascade, but is independent on its pro-oxidant activity (ROS: Reactive Oxygen Species).

Wei et al. [7] and Schroeter et al. [8] both have showed that induction of apoptosis by quercetin but could not confirm the apoptotic mechanism. Caspase cascade has been shown to be involved in the action of apoptosis. Caspase 3 is an executioner caspase, and exists in the cytoplasm as an inactive pro-caspase 3 that becomes proteolytically activated by multiple cleavages in apoptotic cells.

Quercetin has been shown to reduce cell proliferation, causing cell-cycle arrest in the G0/G1 phase, the S phase, and the G2/M phase in in vitro experiments with various cell lines [9-11]. Rusak et al. [12] suggested that the different effects off flavonoids on the cycle and proliferation of cells is cell-type specific. Their data indicate that Lactucaindica L. induces a G0/G1 block in HL-60 cells.

In the past decade, a very large number of proto-oncogenes and tumor suppressor genes have been found. Recently, up regulated gene $4(U R G 4 / U R G C P)$, a novel gene up regulated by $\mathrm{HBxAg}$ in human hepatocellular carcinoma, has been identified (Gen Bank accession no. NM_017920). Previous data suggested that overexpression of URG4/ $U R G C P$ in HepG2 cells promoted hepatocellular growth and survival in tissue culture and nude mice. Hence, URG4 maybe an oncogene operating in hepatocarcinogenesis [6].

The mechanism of URG4/URGCP biologic activity in normal and 
Citation: Dodurga Y, Avci CB, Lale Satiroglu-Tufan N, Susluer SY, Ozlem Dogan Sigva Z, et al. (2012) Effects of Quercetin Induced Cell Death on a Novel Gene "URG4/URGCP" Expression in Leukemia Cells. J Cancer Sci Ther 4: 006-009. doi:10.4172/1948-5956.1000102

malignant cells is not yet fully understood. Song et al. [13] showed that $U R G 4 / U R G C P$ was up regulated in human gastric cancer tissues and also in gastric cancer cell lines and overexpression of $U R G 4 / U R G C P$ could promote cell proliferation.

Huang et al. [14] described in their data URG4/URGCP was highly expressed in 40 of 46 (86.96\%) osteosarcoma specimens with cytoplasmic staining, and also increased in the specimens with recurrence $(\mathrm{p}<0.05)$ and metastasis $(\mathrm{p}<0.05)$. They thought that $U R G 4 /$ $U R G C P$ may play important roles in the development of osteosarcoma, and might be a useful molecular marker for predicting the prognosis of osteosarcoma.

In this study, we investigated anti-proliferative and apoptotic effects of quercetin on human leukemia cells and effects of quercetin induced cell death on a novel gene URG4/URGCP expression in leukemia cells. It was found that quercetin diminishes URG4/ $U R G C P$ gene expression in leukemia cell lines. Our ongoing studies include the detailed investigation of URG4's molecular function in oncogenic signaling pathways and cell cycle regulation. Based on our results of growth inhibition and apoptosis induction data, URG4 gene expression is suppressed by quercetin and also this correlation is inhibited cell cycle and induced apoptosis by quercetin. URG4/URGCP plays an important role in the development of leukemia, and might be a useful molecular marker for predicting the prognosis of leukemia via quercetin treatment. Controlled clinical trials are needed to show whether quercetin has a positive effect on cancer treatment [15-17].

\section{References}

1. Sun SW, Yu HQ, Zhang H, Zheng YL, Wang JJ, et al. (2007) Quercetin attenuates spontaneous behavior and spatial memory impairment in d-galactose-treated mice by increasing brain antioxidant capacity. Nutr Res 27: 169-175.

2. Ishige K, Schubert D, Sagara $Y(2001)$ Flavonoids protect neuronal cells from oxidative stress by three distinct mechanisms. Free RadicBiol Med 30: 433446.

3. Chen J, Ou YX, Da WM, Kang JH (2004) Coadjustment of quercetin and hydrogen peroxide: the role of ROS in the cytotoxicity of quercetin. Pharmazie 59: $155-158$.

4. Chen J, Kang JH, Da WM, Ou YX (2004) Combination with water-soluble antioxidants increases the anticancer activity of quercetin in human leukemia cells. Pharmazie 59: 859-863.

5. Kuo HM, Ho HJ, Chao PD, Chung JG (2002) Quercetin glucuronides inhibited 2-aminofluorene acetylation in human acute myeloid HL-60 leukemia cells. Phytomedicine 9: 625-631.

6. Tufan NL, Lian Z, Liu J, Pan J, Arbuthnot P, et al. (2002) Hepatitis Bx antigen stimulates expression of a novel cellular gene, URG4, that promotes hepatocellular growth and survival. Neoplasia 4: 355-368.

7. Wei YQ, Zhao X, Kariya Y, Fukata H, Teshigawara K, et al. (1994) Induction of apoptosis by quercetin: involvement of heat shock protein. Cancer Res 54: 4952-4957.

8. Schroeter H, Spencer JP, Rice-Evans C, Williams RJ (2001) Flavonoids protect neurons from oxidized low-density-lipoprotein-induced apoptosis involving C-Jun N-terminal kinase (JNK), c-Jun and caspase-3. Biochem J 358: 547-557.

9. Yoshida M, Yamamoto M, Nikaido T (1992) Quercetin arrests human leukemic T-cells in late G1 phase of the cell cycle. Cancer Res 52: 6676-6681.

10. Richter M, Ebermann R, Marian B (1999) Quercetin-induced apoptosis in colorectal tumor cells: possible role of EGF receptor signaling. Nutr Cancer 34: 88-99.

11. Lee TJ, Kim OH, Kim YH, Lim JH, Kim S, et al. (2006) Quercetin arrests G2/M phase and induces caspase-dependent cell death in U937 cells. Cancer Let 240: 234-242.

12. Rusak G, Gutzeit HO, Muller JL (2005) Structurally related flavonoids with antioxidative properties differentially affect cell cycle progression and apoptosis of human acute leukemia cells. Nutr Res 25: 143-155.

13. Song J, Xie H, Lian Z, Yang G, Du R, et al. (2006) Enhanced cell survival of gastric cancer cells by a novel gene URG4. Neoplasia 8: 995-1002.

14. Huang J, Zhu B, Lu L, Lian Z, Wang Y, et al. (2009) The expression of nove gene URG4 in osteosarcoma: correlation with patients' prognosis. Pathology 41: 149-154.

15. Puissant A, Grosso S, Jacquel A, Belhacene N, Colosetti P, et al. (2008) Imatinib mesylate-resistant human chronic myelogenous leukemia cell lines exhibit high sensitivity to the phytoalexin resveratrol. FASEB J 22: 1894-1904.

16. Avcı CB, Gündüz C, Baran Y, Sahin F, Yılmaz S, et al. (2011) Caffeic acid phenethyl ester triggers apoptosis through induction of loss of mitochondrial membrane potential in CCRF-CEM cells. J Cancer Res Clin Oncol 137: 41-47.

17. Niu G, Yin S, Xie S, Li Y, Nie D, et al. (2010) Quercetin induces apoptosis by activating caspase- 3 and regulating $\mathrm{Bcl}-2$ and cyclooxygenase-2 pathways in human HL-60 cells. Acta Biochim Biophys Sin (Shanghai) 43: 30-37. 